РАТУШНЯК Наталья Александровна - преподаватель, Обособленное структурное подразделение

«Технологически-промышленный профессиональный колледж Винницкого национального аграрного университета» (21021, г. Винница, проспект Юности, 8, e-mail: nata.ratusnak8913@gmail.com).

\author{
ПОХИЛЕНКО Н.М., \\ кандидат економічних наук, \\ стариий науковий співробітник відділу організації \\ менеджменту, публічного управління та \\ адміністрування, \\ ННЦ «Інститут аграрної економіки»
} ГОСПОДАРСЬКОЇ ДОРАДЧОї ДІЯЛЬНОСТІ В УКРАЇ̈I
КОРІНЕЦЬ Р.Я., кандидат економічних наук, почесний президент Національної асоціації сільськогосподарських дорадчих службб Украйни

(м. Kuїв)

У статті проаналізовано поточний стан фінансового забезпечення сочіальноспрямованих дорадчих послуг в Украйні з метою виявлення перешкод стабільності та регулярності його здійснення. На основі статистичних даних встановлено, щуо фінансування такої діяльності з державного бюджету має низхідну тендениію. Його обсяги подекуди у десятки тисяч разів менші, ніж аналогічні бюджетні видатки у постсоиіалістичних країнах, які нині є членами ЄС. Результати опитування представників дорадчих служб засвідчили, щуо причиною низької активності зареєстрованих сільськогосподарських дорадчих служб у реалізачії державних програм підтримки сільськогосподарських виробників та, відповідно, неповного освоєння виділених коштів $\epsilon$ мізерність, непрогнозованість та нестабільність державної підтримки сільськогосподарської дорадчої діяльності, слабкість пов'язаності між собою державних програм, які спрямовані на розвиток аграрної сфери економіки. Також виявлено нерозуміння важливості дорадництва представниками органів місиевого самоврядування. Доведено, щуо консерватизм щзодо запровадження інновачій власниками невеликих господарств, низький рівень пізнаваності ними сільськогосподарського дорадництва, значна віддаленість осередків дорадництва від потенційних клієнтів, низький рівень доходів сільського населення мінімізують їхню спроможність оплачувати комериійні дорадчі послуги. Встановлено, щзо фінансові та організаційні труднощчі мають значний негативний вплив на психологічні аспекти дорадчої діяльності. Дорадники заявляють про відсутність віри у власні сили. Результати дослідження дозволяють стверджувати, щзо формування стабільних, простих $i$ зрозумілих правил державного фінансування дорадчої діяльності на тривалу перспективу та безумовне дотримання таких правил державними інституціями сприятиме підвищенню стійкості фінансового забезпечення сільськогосподарської дорадчої діяльності в Украӥні.

Ключові слова: фінансове забезпечення, дорадча діяльність, державне фінансування дорадництва, опитування, сільське господарство, економіка України.

Табл.: 2. Рис.: 4. Літ.: 21. 


\title{
PROBLEMS OF FINANCING OF AGRICULTURAL EXTENSION ACTIVITIES IN UKRAINE
}

\author{
POKHYLENKO Nataliia, \\ Candidate of Economic Sciences, \\ Senior Researcher of the Department of Organization \\ of Management, Public Administration and Administration, \\ National Scientific Center "Institute of Agrarian Economics»
}

\author{
KORINETS Roman, \\ Candidate of Economic Sciences, \\ Honorary President of the National Association \\ of Agricultural Extension Services of Ukraine
}

(Kyiv)

The article analyzes the current state of financial support for socially oriented extension services in Ukraine in order to identify the obstacles to stability and regularity of its implementation. It has been established on the basis of statistical data, that the financing of such activities from the state budget has a downward trend. Its volumes are tens of thousands of times less than similar budgetary expenditures in post-socialist countries that are currently EU members. The results of a survey of representatives of consulting services showed that the reason for the low activity of the registered agricultural extension services in the implementation of state programs to support agricultural producers and, accordingly, the incomplete development of the allocated funds are the scarcity, unpredictability and instability of state support for agricultural extension activities, the weakness of the coherence between themselves of the state programs, aimed at the development of the agricultural sector of economy. There is also a lack of understanding of the importance of agricultural extension by local government representatives. It is proved that conservatism in the introduction of innovations by owners of small farms, low level of awareness of agricultural extension, significant distance of advisory centers from potential customers, low income of the rural population minimize their ability to pay for commercial advisory services. It is established that financial and organizational difficulties have a significant negative impact on the psychological aspects of counseling. Advisors declare a lack of faith in their own strength. The results of the study allow us to assert that the formation of stable, simple and clear rules for long term state financing of agricultural extension activities and the absolute abidance of such rules by state institutions will help to increase the sustainability of financial support for agricultural extension activities in Ukraine.

Key words: financial support, agricultural extension activity, state funding of agricultural extension service, the poll, agriculture, economy of Ukraine.

Tabl.: 2. Fig.: 4. Ref.: 21.

\section{ПРОБЛЕМЫ ФИНАНСОВОГО ОБЕСПЕЧЕНИЯ СЕЛЬСКОХОЗЯЙСТВЕННОЙ КОНСУЛЬТАЦИОННОЙ ДЕЯТЕЛЬНОСТИ В УКРАИНЕ}




\title{
EФМ
}

http://efm.vsau.org/

ПОХИЛЕНКО Н.М., кандидат экономических наук, старший научный сотрудник отдела организации менеджмента, публичного управления и администрирования, Национальный научный центр «Институт аграрной экономики»

\author{
КОРИНЕЦР.Я., \\ кандидат экономических наук, \\ советник Национальной ассоциации \\ сельскохозяйственных консультационных служб Украины \\ (2. Киев)
}

В статье проанализировано текущеее состояние финансового обеспечения социально-
направленных консультационных услуг в Украине с иелью определения препятствий стабильности и регулярности его осуществления. На основе статистических данных установлено, что финансирование такого рода деятельности из государственного бюджета имеет нисходямую тенденщию. Его объемы в десятки тысяч раз меньше, чем аналогичные бюджетные расходы в постсочиалистических странах, которые в настоящее время являются членами ЕС. Результаты опроса представителей консультационных служб показали, что причиной низкой активности зарегистрированных сельскохозяйственных консультаџионных служб в реализаџии государственных программ поддержки сельскохозяйственных производителей и, соответственно, неполного освоения выделенных средств является скудность, непредсказуемость и нестабильность государственной поддержски сельскохозяйственной консультационной деятельности, слабость связанности между собой государственных программ, направленных на развитие аграрной сферы экономики. Также обнаружено непонимание важности консультирования представителями органов местного самоуправления. Доказано, что определенный консерватизм относительно внедрения инноваций владельцами небольших хозяйств, низкий уровень узнаваемости сельскохозяйственного консультирования, значительная удаленность информационно-консультационных цеентров от потенцииальных клиентов, низкий уровень доходов сельского населения минимизируют их способность оплачивать коммерческие консультационные услуги. Установлено, что финансовые и организационные трудности оказывают значительное негативное влияние на психологические аспекты консультационной деятельности. Консультанты заявляют об отсутствии веры в собственные силь. Результаты исследования позволяют утверждать, что формирование стабильных, простых и понятных правил государственного финансирования консультационной деятельности на длительную перспективу и безусловное соблюдение таких правил государственными институтами будут способствовать повымению устойчивости финансового обеспечения сельскохозяйственной консультационной деятельности в Украине.

Ключевые слова: финансовое обеспечение, информационно-консультационная деятельность, государственное финансирование консультирования, опрос, сельское хозяйство, экономика Украины.

Табл.: 2. Рис.: 4. Лит.: 21.

Постановка проблеми. У світовій практиці сільськогосподарське дорадництво виступає одним із потужних рушіїв інноваційного розвитку 
аграрної галузі, впливаючи на спроможність виробників сільськогосподарської продукції освоювати новітні технології, оперативно використовувати ринкову кон’юнктуру та здійснювати ефективне управління господарствами. Дедалі вагоміше постає завдання навчити селян творчо мислити, вміти ухвалювати самостійні рішення на основі аналізу їхнього економічного та соціального середовища.

Однак, наявні в Україні потужності мережі сільськогосподарських дорадчих служб не дозволяють здійснювати помітний вплив ні на інноваційний розвиток аграрного сектора, ні на розвиток сільських територій. У цьому контексті питання стійкості фінансового забезпечення такої діяльності набуває особливої актуальності.

Аналіз останніх досліджень і публікацій. Дослідженню наслідків зміни підходів до фінансового забезпечення систем сільськогосподарського дорадництва присвячено роботи низки зарубіжних вчених, серед яких: Пол Е. МакНамара [1], Гершон Федер, Ентоні Віллет, Віллем Зіп [2] Елізабез Катз, Вільям М. Рівера, М. Калім Камар, Л. Ван Клоудер, Джонатан Бейнон та інші. Вітчизняні дослідники такі як Жураковська Л.А., Григор'єва Х.А., Кропивко М.Ф. [4], Брояка А.А. [5] наголошують на недостатності обсягів фінансового забезпечення соціально-спрямованих дорадчих послуг із бюджетів різних рівнів (державного, обласних, місцевих) та виокремлюють неналежну організацію його здійснення як один із найвагоміших стримуючих факторів розвитку сільськогосподарського дорадництва. Водночас, віддаючи належне науковим напрацюванням учених у вивченні цієї проблематики, системних досліджень причин такого стану в Україні, серед проаналізованих джерел інформації, не виявлено.

Формулювання цілей статті. Мета наукового дослідження полягає в аналізі поточного стану фінансового забезпечення дорадчої діяльності для виявлення проблем, які перешкоджають стабільності та регулярності такого забезпечення.

Виклад основного матеріалу дослідження. В Україні законодавчо закріплена можливість надання комерційних та соціально-спрямованих дорадчих послуг. Джерелами фінансування перших виступають кошти суб'єктів господарювання, а других - можуть виступати кошти державного та місцевих бюджетів, а також грантів, міжнародної технічної допомоги, коштів міжнародних програм і проєктів, благодійних внесків фізичних та юридичних осіб, інших джерел, не заборонених законом. У цій публікації увага буде зосереджена на аналізі перешкод фінансового забезпечення соціальноспрямованих дорадчих послуг.

За результатами дослідження з'ясовано, що практика фінансування сільськогосподарської дорадчої діяльності з державного бюджету демонструє низхідну тенденцію на фоні неповного освоєння дорадчими службами вже виділених державних коштів (рис. 1). 


\section{EФМ}

http://efm.vsau.org/

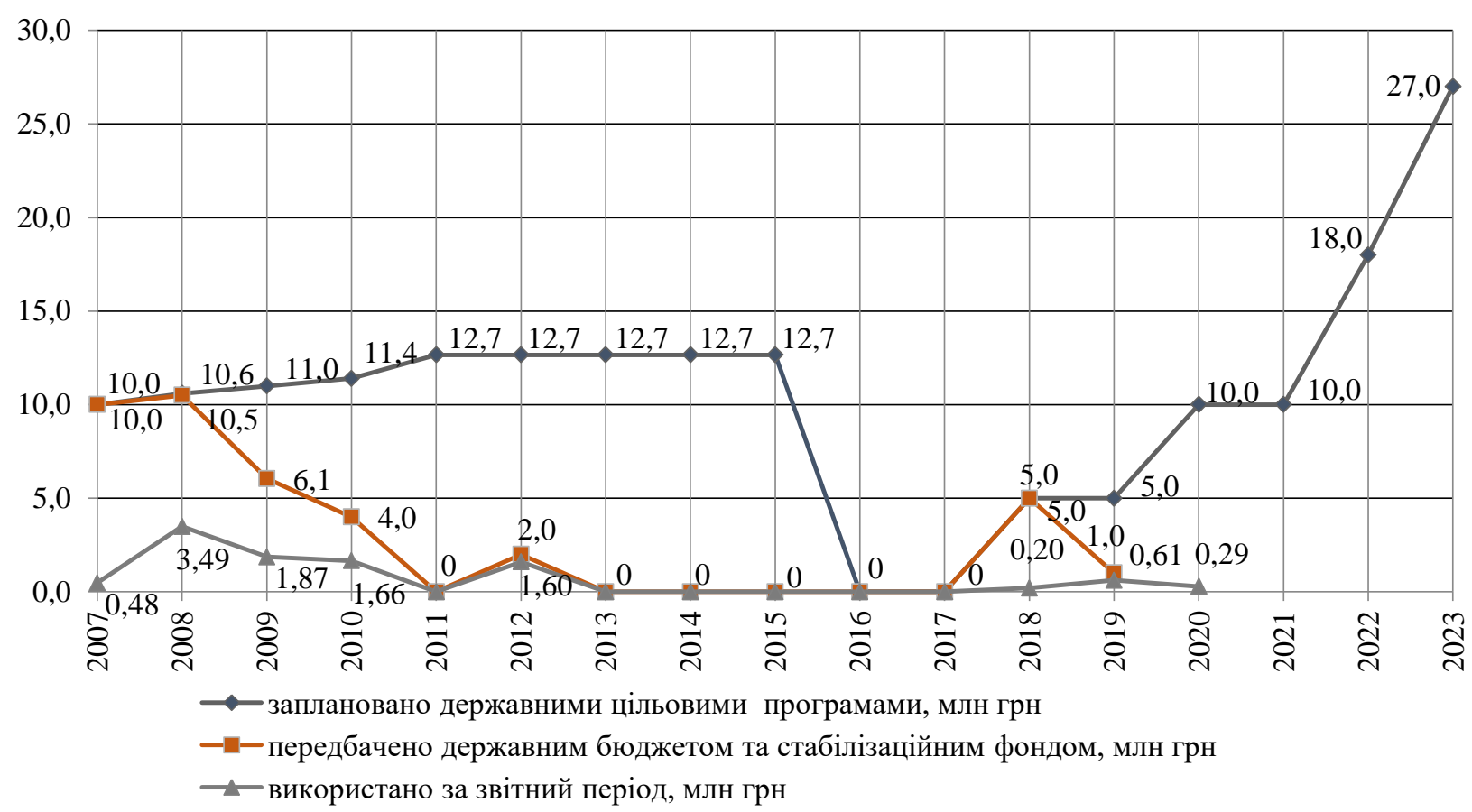

\section{Рис.1. Обсяги фінансування дорадчої діяльності з Державного бюджету України}

Джерело: сформовано авторами за даними джерел [5-9]

Так, у період 2007-2012 рр. частка фактично виділених на дорадчу діяльність із Державного Бюджету (далі - ДБ) України та Стабілізаційного фонду до запланованих державними цільовими програмами коштів на ці цілі скоротилось на $84,2 \%$ (із $100 \%$ у 2007 році до $15,8 \%$ у 2012 році). Натомість частка освоєних сільськогосподарськими дорадчими службами до виділених із ДБ України та стабілізаційного фонду коштів у зазначений період зросла на $75 \%$ ( $3 \%$ у 2007 році до $80 \%$ у 2012 році), і в середньому склала $64 \%$. Тобто, у програмних документах обсяги фінансового забезпечення такої діяльності скорочувались тоді, коли дорадчі служби демонстрували підвищення спроможності виконувати державне замовлення, хоча й не досягали цієї цілі в повному обсязі. У 2013-2017 рр. фінансування такої діяльності з ДБ України припинилося. Відновлення фінансування дорадчої діяльності з 2018 року в межах програми державної підтримки сільгоспвиробників, а саме «Фінансова підтримка розвитку фермерських господарств», $\epsilon$ проявом «традиції» неспівставлення запиту державних органів на обсяг виконаних робіт та можливостей суб'єктів дорадчої діяльності їх задовольняти, в тому числі в рамках існуючих процедур. Відповідно рівень освоєння виділених із ДБ коштів у період 2018-2019 рр. склав 8\% (у 2018 р. освоєно 4\%, а у 2019 р. - 12\%).

Слід зауважити, що не всі дорадчі служби (далі - ДС) погоджуються брати участь у реалізації програми державної підтримки фермерів. Так, у період 2018-2019 pр. їх частка від загальної кількості внесених до Реєстру дорадчих служб склала $25 \%$ (у 2018 році - 3 з 12 ДС, у 2019 році - 4 з 16 ДС), а у 
2020 році - 23\% (6 із 26 ДС) [10]. Це може свідчити про певну обережність ДС у співпраці з державними органами влади, проблемами вчасного виділення таких коштів та складністю процедур їх отримання.

У пошуку причин такої поведінки представників ДС також звертаємо увагу на питання ревалентності оцінювання праці дорадників державними органами. Тож пропонуємо співставити обсяги державної підтримки дорадчої діяльності 3 державними інвестиціями в аграрну галузь, а також порівняти 3 обсягами оплати праці в галузі та співставити заробітну плату дорадників із аналогічною діяльністю, що здійснюється іншими організаціями.

За дослідженням Місра Д.С. [11] можливості здійснення дорадчої діяльності розглядаються як здатність фізичних, фінансових та людських ресурсів - суб'єктів сільськогосподарського дорадництва до обслуговування клієнтів (фермерів). Отож рівень державної підтримки дорадчої діяльності в Україні пропонуємо розглянути, спираючись на визначені дослідником індикатори фінансів, інвестицій та пов'язаності інвестицій в аграрну галузь. Індикатор фінансів визначено науковцем як частку бюджетних витрат на сільськогосподарське дорадництво в загальних бюджетних витратах на сільське господарство протягом року, а індикатор інвестицій - як частку витрат на сільськогосподарське дорадництво від сільськогосподарського валового внутрішнього продукту в рік. Пов'язаність інвестицій в аграрну галузь розглянемо як частку державних інвестицій у дорадчу діяльність щодо фінансування прикладних досліджень у сфері сільськогосподарських наук (табл. 1).

Таблиця 1

Питома вага фінансування дорадчої діяльності за часткою сільського господарства у ВВП, програмами підтримки розвитку АПК та витрат із державного бюджету на прикладні наукові дослідження

в Україні у 2018-2020 pp.

\begin{tabular}{|c|c|c|c|c|c|c|c|}
\hline \multirow[b]{2}{*}{ Роки } & \multirow[b]{2}{*}{$\begin{array}{c}\text { Фактичні } \\
\text { витрати з ДБ } \\
\text { на дорадчу } \\
\text { діяльність, } \\
\text { млн грн }\end{array}$} & \multirow[b]{2}{*}{$\begin{array}{c}\text { Частка } \\
\text { сільського } \\
\text { господарства } \\
\text { у ВВП у } \\
\text { фактичних } \\
\text { цінах, } \\
\text { млн грн }\end{array}$} & \multirow[b]{2}{*}{$\begin{array}{c}\text { Фактично } \\
\text { спрямовано з } \\
\text { ДБ виконавцям } \\
\text { програм } \\
\text { підтримки } \\
\text { розвитку АПК, } \\
\text { млн грн. } \\
\end{array}$} & \multirow[b]{2}{*}{$\begin{array}{c}\text { Фактичні витрати з ДБ } \\
\text { на прикладні наукові та } \\
\text { науково-технічні } \\
\text { розробки у сфері } \\
\text { сільськогосподарських } \\
\text { наук, млн грн. }\end{array}$} & \multicolumn{3}{|c|}{ Індикатори } \\
\hline & & & & & 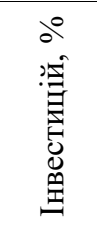 & 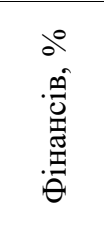 & 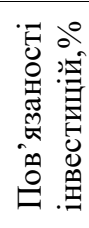 \\
\hline 2018 & 0,202 & 361173,0 & 3505,8 & 822,9 & 0,006 & 0,006 & 0,025 \\
\hline 2019 & 0,613 & 356795,0 & 2580,4 & 100,8 & 0,017 & 0,024 & 0,608 \\
\hline 2020 & 0,286 & 388726,0 & 3973,9 & 136,3 & 0,007 & 0,007 & 0,210 \\
\hline
\end{tabular}

Встановлено що збільшення втричі фактичних витрат на дорадчу діяльність із ДБ у 2019 році порівняно 3 попереднім роком забезпечило збільшення за індикатором інвестицій лише на $0,017 \%$, за індикатором фінансів - на $0,024 \%$, а за індикатором пов'язаності інвестицій 


\section{EФM}

http://efm.vsau.org/

сільськогосподарської науки і дорадництва - на 0,608\%, що свідчить про мізерність державної підтримки такого виду діяльності та слабкість пов'язаності між собою державних програм, спрямованих на розвиток аграрної сфери економіки.

У таких умовах постає питання адекватності оцінювання праці дорадників відносно обсягів оплати праці в аграрній галузі. Якщо обсяг освоєних дорадчими службами коштів із ДБ прирівняти до фонду оплати праці, то виявляється, що місячна заробітна плата жодного дорадника не досягла рівня заробітної плати у сільському господарстві, оскільки перебуває на рівні трохи вище прожиткового мінімуму (табл. 2).

Таблиия 2

Порівняння доходів кадрового складу ДС з номінальною заробітною платою у сільському господарстві та прожитковим мінімумом для

\section{працездатних осіб за регіонами України станом на кінець 2020 року}

\begin{tabular}{|c|c|c|c|c|c|c|}
\hline \multirow[b]{2}{*}{ Область } & \multirow[b]{2}{*}{$\mid \begin{array}{c}\text { Кількісний } \\
\text { склад ДС, } \\
\text { осіб }\end{array}$} & \multicolumn{3}{|c|}{$\begin{array}{c}\text { Отримано ДС компенсації із ДБ, } \\
\text { тис. грн }\end{array}$} & \multirow[b]{2}{*}{$\begin{array}{c}\text { Отримано ДС } \\
\text { компенсації із ДБ } \\
\text { відносно прожиткового } \\
\text { мінімуму для } \\
\text { працездатних осіб, \% }\end{array}$} & \multirow{2}{*}{\begin{tabular}{|c} 
Отримано ДС \\
компенсації із ДБ \\
відносно \\
номінальної \\
заробітної плати \\
у сільському \\
господарстві, \%*
\end{tabular}} \\
\hline & & $\begin{array}{c}\text { Отримано } \\
\text { ДС всього, } \\
\text { тис. грн }\end{array}$ & $\begin{array}{c}\text { на } 1 \text { працю- } \\
\text { ючого в ДС, } \\
\text { грн у рік }\end{array}$ & $\begin{array}{c}\text { на } 1 \\
\text { працюючого } \\
\text { в ДС, } \\
\text { грн у міс. }\end{array}$ & & \\
\hline Вінницька & 5 & 33,8 & 6760 & 563 & 26 & 6 \\
\hline Дніпропетровська & 9 & 18,7 & 2078 & 173 & 8 & 2 \\
\hline Кіровоградська & 3 & 9,0 & 3000 & 250 & 11 & 3 \\
\hline Полтавська & 3 & 94,2 & 31400 & 2617 & 120 & 30 \\
\hline Тернопільська & 3 & 89,4 & 29800 & 2483 & 113 & 28 \\
\hline Харківська & 4 & 41,5 & 10375 & 865 & 39 & 10 \\
\hline
\end{tabular}

Джерело: розраховано авторами за даними джерел [16, с. 22; 17]

Так, серед дорадчих служб, які взяли участь у реалізації державних програм підтримки сільськогосподарських виробників протягом 2020 року, у Дніпропетровській області дорадники отримали заробітну плату, в перерахунку на середньомісячний розмір, на рівні 8\% прожиткового мінімуму в Україні, натомість у Полтавській області - перевищили його лише на $20 \%$. Це є свідченням значного знецінення складної інтелектуальної праці дорадників державними органами та $\epsilon$ вагомим демотивуючим фактором їх участі у реалізації державних програм.

Порівнюючи обсяги державної підтримки дорадчої діяльності в Україні 3 країнами пострадянського простору, а саме Латвією, Естонією, Польщею, слід відзначити мізерність вітчизняних інвестицій із бюджету на таку діяльність. У той час як Україна лише знайомилась із поняттям сільськогосподарської дорадчої діяльності, в Латвії Міністерством сільського господарства й Латвійською федерацією фермерів було засновано ТОВ «Латвійський центр сільськогосподарських консультацій та освіти» (SIA «Latvijas Lauku konsultāciju un izglìtības Centrs», далі - LLKC). Тривала і плідна 30-ти річна співпраця цих інституцій дозволила LLKC у 2019 році мати оборот обсягом 11,174 млн євро, в 
тому числі за рахунок державного фінансування - 3,856 млн євро [18], що перевищує в 163 рази фактичні розміри української «підтримки». Останні отримали державної підтримки на суму 0,024 млн євро (або 0,61 млн грн) за курсом НБУ станом на 23.12.2019 p. [19].

Цікавим для України $є$ також досвід державного фінансового забезпечення дорадчої діяльності в Естонії із точки зору відсутності протягом тривалого часу організаційної структури загальнодержавного масштабу. Але 3 липня 2015 року у складі Фонду розвитку сільських територій (далі - Фонд сільського розвитку) працює консультативна служба в галузі сільського господарства та розвитку сільських територій, що надає консультативні послуги жителям сіл та малих містечок. На основі конкурсного відбору Фонд сільського розвитку обрано постачальником дорадчих послуг на період 20152021 рр. на загальну суму 8,2 млн євро. Угодою на постачання дорадчих послуг передбачено покриття 95\% витрат на наданні послуги 3 Європейського сільськогосподарського фонду розвитку сільських територій та державного бюджету Естонії. У 2019 році із запланованих Фондом сільського розвитку надходжень на суму 1,031 млн євро фактично надано консультаційних послуг на суму 1,119 млн євро. Тобто, за цей рік естонські урядовці передбачили 0,979 млн євро на дорадчу діяльність, що у 25 разів більше, ніж передбачили українські керманичі на аналогічні цілі у ДБ та стабілізаційному фонді (за курсом НБУ станом на 23.12.2019 р.), а фактично компенсовано Фонду сільського розвитку 1,063 млн євро, тоді як в Україні дорадчим службам компенсовано у 45 разів менше, ніж естонським колегам (0,024 млн євро). Примітно, що максимальні розміри компенсації вартості консультаційних послуг на одне естонське фермерське господарство у рік становлять не більше 3 тис. євро [20], тоді як в Україні держава компенсує у 8 разів менше (до 10 тис. грн на одне фермерське господарство, тобто 386,8 євро).

У Польщі фінансування дорадчої діяльності здійснюється в межах Програми розвитку сільських територій на 2014-2020 роки [21] за такими напрямами:

- передача знань та інформаційна діяльність (професійне навчання i набуття навичок, а також підтримка демонстраційних та інформаційних заходів);

- консультаційні послуги на місцях із управління фермерським господарством (консультування фермерів та власників лісу);

- підтримка місцевого розвитку в рамках ініціативи LEADER (впровадження стратегій місцевого розвитку, проєктів співпраці тощо).

У 2019 році розміри виконаних Європейським сільськогосподарським фондом розвитку сільських територій (EAFRD) спільно з польським державним фондом за зазначеними напрямами склали 378,2 млн євро, що у 15950 рази більше за фактичні розміри вітчизняної підтримки дорадництва.

Висвітлене співвідношення державної підтримки дорадчої діяльності в 


\section{EФM}

http://efm.vsau.org/

різних країнах свідчить, що в умовах євроінтеграційних прагнень державним органам влади Україні слід переглянути як загальний розмір виділених, а не лише запланованих коштів, так і граничні розміри підтримки на одне фермерське господарство.

Для виявлення стримуючих факторів участі дорадників у програмах державної підтримки сільськогосподарських виробників у листопадігрудні 2020 року Національною асоціацією сільськогосподарських дорадчих служб за підтримки Німецько-українського агрополітичного діалогу проведено онлайн-опитування 24-х дорадчих служб із 17 областей України. При дослідженні відповідей на питання «Назвіть три найбільші проблеми, з якими зіштовхується Ваша ДС?», виявлено, що проблема фінансового забезпечення гостро стоїть для всіх учасників опитування, не менш вагомими виступили складнощі державної політики та правового регулювання дорадчої діяльності, а також психологічні й організаційні проблеми. Так, керівники 10-ти ДС або 42\% опитаних засвідчили відсутність будь-яких джерел фінансування у 2019 році, доходи однієї ДС не перевищували 10 тис. грн на рік, а кожна 6-та ДС отримала фінансування в розмірі до 100 тис. грн на рік (рис. 2).
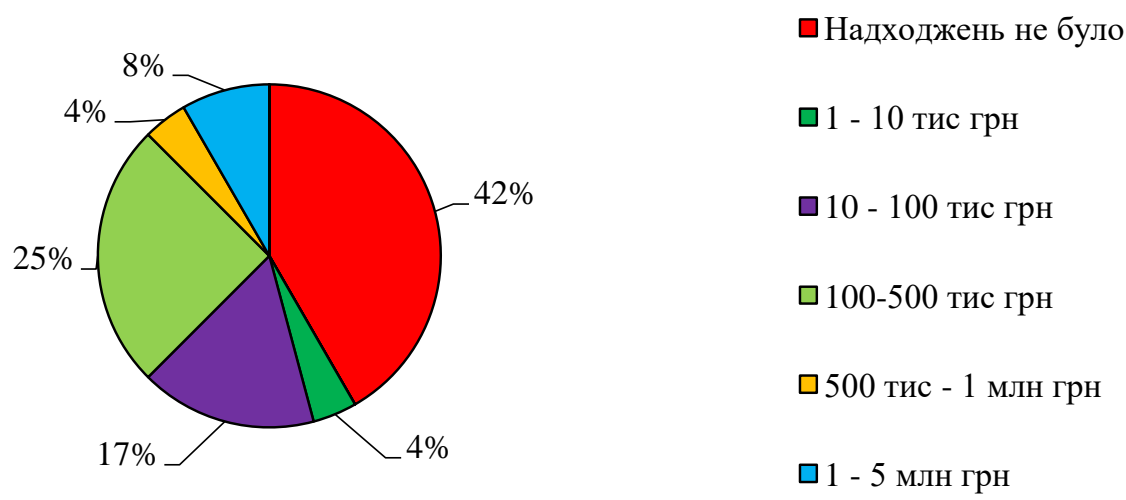

\section{Рис. 2. Відповідь на питання «Яким був розмір бюджету Вашої ДС у 2019 році?» \\ Джерело: розраховано авторами за результатами опитування}

Це змушує дорадників зосереджувати увагу на постійному пошуку джерел фінансування. В таких умовах дорадча діяльність не може стати основним джерелом заробітку дорадників, що негативно позначається на можливості розвитку їхньої компетентності та знижує імідж такого виду діяльності. I лише третина ДС змогли забезпечити річний дохід понад 100 тис. грн: у 25\% опитаних ДС дохід був у межах 100-500 тис. грн, у 4\% 500 тис. -1 млн грн, а у $8 \%-1-5$ млн грн.

Скрутне фінансове становище сільськогосподарського дорадництва в Україні не дозволяє забезпечувати достатній рівень оплати праці персоналу та утримувати офісні приміщення. Як наслідок, у понад 50\% ДС за період 20192020 pp. працівники не отримували заробітну плату, бо часто змушені 
працювати на громадських засадах (рис. 3). У 3-х ДС працюють по 1-2 особі, що складає $13 \%$ опитаних, а обсяги кадрового потенціалу $21 \%$ опитаних представників ДС складають по 3-5 осіб. Хоча представники 2-х ДС охарактеризували обсяг кадрового потенціалу: понад 10 осіб.

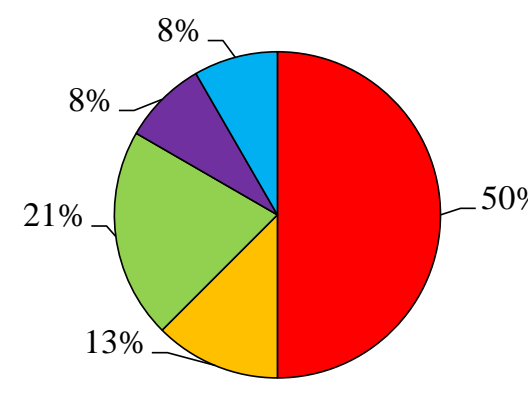

\author{
$\square$ Усі працюють на громадських засадах \\ $\square 1-2$ особи \\ $\square 3-5$ осіб \\ $\square$ 6-10 осіб \\ $\square$ Понад 10 осіб
}

\title{
Рис. 3. Відповідь на питання «Скільки працівників у Вашій ДС отримували офіційну зарплату у 2019-2020 роках?» \\ Джерело: розраховано авторами за результатами опитування
}

Щодо наявності офісних приміщень, то переважна більшість ДС ними забезпечена (рис. 4). Так, 10 ДС (41\%) орендують приміщення, 5 ДС (21\%) отримали робочі місця завдяки допомозі партнерів. У той же час, у 5 з 24 ДС $(21 \%) є$ власний офіс. Однак, кожна 3 6-ти ДС не мають приміщень для здійснення своєї діяльності.
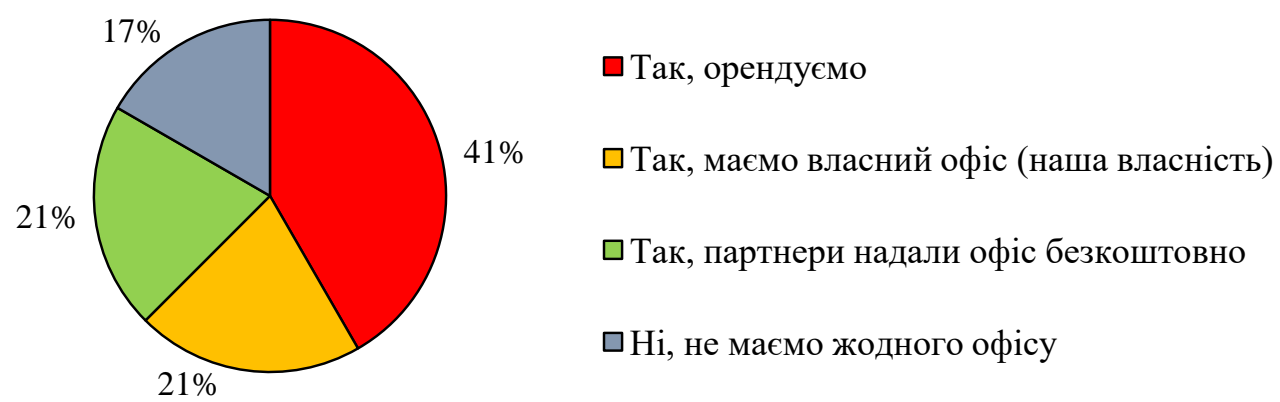

Рис. 4. Відповідь на питання «Чи має Ваша ДС офіс?»

Джерело: розраховано авторами за результатами опитування

Слід звернути увагу, що у структурі доходів ДС перше місце займають кошти, надані міжнародними організаціями (проєкти міжнародної технічної допомоги), друге місце - кошти місцевих бюджетів і третє - кошти Державного бюджету України. Так, доступ до міжнародного фінансування дорадчої діяльності в нашій країні мають лише 44\% опитаних або 11 ДС, досвід отримання коштів із місцевих бюджетів мала кожна 6-та ДС (25\%), а фінансове 


\section{EФM}

http://efm.vsau.org/

забезпечення 3 Державного бюджету в своїй практиці мали тільки $12 \%$ опитаних або кожна 8-ма ДС.

Однак, бачення опитаних щодо того, хто має забезпечувати стабільність, фінансування діаметрально протилежні. Так, $37,5 \%$ опитаних вбачають це відповідальністю держави на національному рівні i, відповідно, нарікають на такі проблеми фінансового забезпечення виконання державних програм підтримки сільськогосподарських виробників (далі - ДП), а саме:

- невиплата ДП;

- неефективна ДП або відсутність дієвої ДП;

- законодавча неврегульованість ДП;

- забюрократизованість, нечітке та невчасне формулювання процедур ДП.

Два респонденти також звертають увагу на відсутність можливості фінансування з Державного Бюджету України групових навчальних заходів. Один акцентує увагу на необхідності здійснення таких заходів для населення, а інший зауважує, що карантинні обмеження через пандемію COVID-19, унеможливили проведення будь-яких групових навчальних заходів.

Частина ДС (13\% опитаних) покладають надії на фінансування з місцевих бюджетів, але стикаються з відсутністю розуміння необхідності дорадництва чи байдужістю до проблем села у очільників області та керівників громад. Відповідно, нерозуміння зумовлює небажання фінансувати ці напрями діяльності.

Кожен третій респондент пов'язує фінансові труднощі їхніх організацій також із специфікою комунікації зі споживачами послуг: фермерськими господарствами (далі - ФГ). Дорадники виділяють такі, перешкоди:

- нерозуміння того, що таке ДС і чим вона може покращити роботу ФГ;

- побоювання ФГ інновацій;

- низький рівень платоспроможності ФГ;

- низький рівень володіння навичками ведення господарства та збуту продукції на ринкових засадах більшістю ФГ;

- особисті селянські господарства (далі - ОСГ) бояться розвиватися та розширювати свою справу;

- пасивність місцевого населення щодо участі у навчальних заходах.

I лише 2 респонденти пов'язали проблеми фінансового забезпечення дорадчої діяльності 3 діяльністю міжнародних організацій із огляду на відсутність міжнародних проєктів по підтримці дорадництва в межах територіального розміщення ДС. Хоча на питання «Чи отримували ви кошти від міжнародних організацій (проєктів)?» ствердною була відповідь у 44\% опитаних.

Психологічні та організаційні аспекти дорадчої діяльності $\epsilon$ також проблематичними. Дорадники заявляють, що втрачають віру у власні сили. Серед виділених ними демотивуючих факторів слід виокремити такі: укрупнення аграрних підприємств, недовіра до дорадників, погана 


\section{EФM \\ http://efm.vsau.org/}

комунікація з консультантами, неможливість знайти фінансово перспективних клієнтів, необізнаність фермерів через відсутність навичок ведення господарства та збуту власної продукції на ринкових засадах, побоювання інновацій, багато ОСГ бояться розвиватися та розширювати свою справу, сільське населення виявляє пасивність щодо участі у навчальних заходах. На низький рівень впізнаваності суб'єктів дорадчої діяльності серед виробників сільськогосподарської продукції вказали $42 \%$ опитаних.

Дослідження праць зарубіжних вчених свідчать, що проблематика стійкості фінансового забезпечення дорадчої діяльності залишається актуальною у багатьох країнах. Пол Е. МакНамара [1] виділяє ряд типових фінансових проблем сільськогосподарського дорадництва для країн, що розвиваються, а саме:

- низький рівень фінансової підтримки галузі державою та фінансовими донорами цих країн;

- спроєктоване донорами фінансове забезпечення дорадчої діяльності не завжди підтримується урядами країн у довгостроковій перспективі;

- ігнорування необхідності забезпечення поточних витрат на дорадчу діяльність виявляється у відсутності чи недостатньому обсязі передбачених у річному бюджеті коштів, або ці кошти перерозподіляються на інші цілі чи зникають у корупційних схемах;

- клаптиковість проєктів міжнародної підтримки, які просувають різні підходи та методології дорадчої діяльності.

Гершон Федер, Ентоні Віллет та Віллем Зіп [2] виділяють такі проблеми сільськогосподарського дорадництва пов'язані з його фінансуванням:

- масштабність і складність сільськогосподарського дорадництва з точки зору кількісної різноманітності дорадчого персоналу (в масштабах країни), цільової аудиторії (як фермерських господарств, так і сільського населення) та зацікавлених сторін (у контексті взаємопов'язаності з сільськогосподарською наукою та освітою), а також із точки зору наданих повноважень та методології діяльності;

- залежність від більш широкої політики (від обсягу інвестицій в інфраструктуру аграрного сектору);

- методологічна проблематика встановлення причинно-наслідкових зв'язків залучених ресурсів та отриманих результатів такої діяльності, що позначається на рівні політичної та обсягах фінансової підтримки.

3 огляду на такі виклики, національні системи сільськогосподарського дорадництва зазнають значних революційних трансформацій, які виражаються в перегляді сфери впливу дорадчої діяльності (від аграрної галузі до сільського розвитку), моделей систем сільськогосподарського дорадництва (від державної власності до повної чи часткової приватизації), переформатування організаційних структур (від централізації до поглиблення децентралізації), забезпеченні плюралізму таких систем, зміни в змісті та методології дорадчої 


\section{EФM}

http://efm.vsau.org/

діяльності (орієнтованість на клієнта та активізація його участі у прийнятті рішень), активізації застосування електронних інформаційних технологій.

Тож, проєктування механізму фінансового забезпечення соціальноспрямованих дорадчих послуг має розглядатися не лише з точки зору його обсягів, а й ретельного проєктування та розподілу фінансових потоків державних коштів на таку діяльність, контролю результативності їх використання та пов'язаності державних інвестицій у дорадчу, освітню та наукову діяльність.

Висновки. Відсутність стабільних джерел фінансування системи сільськогосподарського дорадництва в Україні зумовлює повільний розвиток іiі мережі на місцевому рівні. Фінансове забезпечення 3 державного бюджету такої діяльності має низпадаючу тенденцію. Його обсяги є значно меншими, ніж аналогічні бюджетні видатки у постсоціалістичних країнах - теперішніх членів СС.

Мізерність, нестабільність державної підтримки сільськогосподарської дорадчої діяльності, слабкість пов'язаності з даною діяльністю державних програм, які спрямовані на розвиток аграрної сфери економіки, непрогнозована поведінка держави в частині дорадництва не сприяє залученню висококваліфікованих фахівців у цю сферу. Відповідно, надання соціальноспрямованих дорадчих послуг є непривабливим для більшості зареєстрованих сільськогосподарських дорадчих служб, що спричиняє неповне освоєння дорадчими службами бюджетних коштів. Представники органів місцевого самоврядування також виявляють нерозуміння важливості дорадництва, тому фінансування такої діяльності із місцевих бюджетів знаходиться на низькому рівні.

Дослідження свідчать про готовність частини сільського населення оплачувати дорадчі послуги. Водночас, певний консерватизм щодо запровадження інновацій власниками невеликих господарств, недостатня пізнаваність сільськогосподарського дорадництва, розміщення осередків дорадництва на значній відстані від їхніх потенційних одержувачів, низька платоспроможність сільського населення мінімізують можливість надання дорадчих послуг на комерційних засадах.

Зазначене дозволяє стверджувати, що ключовою перешкодою стабільності та регулярності фінансового забезпечення такої діяльності є слабкі інститути дорадництва. Усунути їх можна тільки політичними інструментами через формування стабільних, простих i зрозумілих правил державного фінансування дорадчої діяльності на тривалу перспективу та їхнє безумовне дотримання державними інституціями та іншими учасниками ринку дорадчих послуг.

\section{Список використаних джерел}

1. McNamara P.A. Review of sustainable financing of extension services in 
developing countries. University of Illinois at Urbana-Champaign. 2014. URL: $\quad$ https://meas.illinois.edu/wp-content/uploads/2015/04/McNamara-2014Finance-MEAS-Discussion-Paper.pdf (дата звернення 15.02.2021).

2. Feder G., Willett A., Zijp W. Agricultural Extension: Generic Challenges and Some Ingredients for Solutions. 1999. URL: https://ssrn.com/abstract=620481 (дата звернення 02.02.2021).

3. Щодо державної підтримки розвитку сільськогосподарського дорадництва в Україні. Аналітична записка. Національний інститут стратегічних досліджень. URL: http://www.niss.gov.ua/articles/1521/ (дата звернення: 19.05.2021).

4. Кропивко М.Ф. Шляхи розвитку сільськогосподарського дорадництва в Україні. Науковий вісник НУБіП України. Серія «Економіка, аграрний менеджмент, бізнес». 2011. Вип. 168. С. 10-16.

5. Брояка А.А. Концептуальні засади організації ефективного інформаційно консультаційного забезпечення сільського господарства. Агросвіт. 2016. № 21. С. 36-42.

6. Похиленко Н.М., Корінець Р.Я. Фінансування системи сільськогосподарського дорадництва. Глобальні та національні проблеми економіки. 2018. № 23. С. 109-115.

7. Про результати аудиту ефективності використання коштів державного бюджету, спрямованих на виконання Державної цільової програми розвитку українського села на період до 2015 року. Київ: Рахункова палата України, 2015.39 c.

8. Паспорт бюджетної програми 2801230 «Фінансова підтримка розвитку фермерських господарств»: затверджений наказом Міністерства аграрної політики та продовольства України від 18.06 .2019 p № 329 URL: https://agro.me.gov.ua/ ua/napryamki/finansova-politika/byudzhetnijproces/pasporti-byudzhetnih-program/pasporti-byudzhetnih-program-na-2019-rik (дата звернення: 19.05.2021).

9. Держпідтримка АПК: фокус у 2020 році та стратегія на 2021-2023 роки. Агрополіт. URL: https://agropolit.com/spetsproekty/783-derjpidtrimka-apk-fokus-u2020-rotsi-ta-strategiya-na-20212023-roki (дата звернення 30.05.2021).

10. Реєстр сільськогосподарських дорадчих служб. Інформаційноаналітичний портал АПК України. URL: https://agro.me.gov.ua/ua/ filestorage/reyestr-doradchih-sluzhb-ta-doradnikiv (дата звернення 12.05.2021).

11. Misra D.C. Monitoring extension programmes and resources. Improving agricultural extension. A reference manual. Food and Agriculture Organization of the United Nations. 1997. URL: http://www.fao.org/ docrep/W5830E/w5830e0j.htm\#monitoringindicators (дата звернення 14.05.2021).

12. Звіт про виконання паспорта бюджетної програми КПКВК 6591060 Національна академія аграрних наук України. URL: http://naas.gov.ua/upload/iblock/df5/\%D0\%B7\%D0\%B2\%D1\%96\%D1\%82\%20659 


\section{EФM}

http://efm.vsau.org/

1060.pdf (дата звернення 12.04.2021).

13. Стан фінансування АПК у 2018 році. Інформаційно-аналітичний портал АПК України. URL: https://agro.me.gov.ua/ua/napryamki/finansovapolitika/finansuvannya-z-derzhavnogo-byudzhetu/stan-finansuvannya-apk-u-2018roci (дата звернення 13.04.2021).

14. Стан фінансування АПК у 2019 році. Інформаційно-аналітичний портал АПК України. URL: https://agro.me.gov.ua/ua/napryamki/finansovapolitika/finansuvannya-z-derzhavnogo-byudzhetu/stan-finansuvannya-apk-u-2019roci (дата звернення 13.04.2021).

15. Національні рахунки (ВВП). Державна служба статистики України. URL: http://ukrstat.gov.ua/imf/arhiv/nr/nr2016_2020_u.htm (дата звернення 13.04.2021).

16. Сільське господарство України за 2019 рік. Статистичний збірник. Київ. $2020 \quad$ URL: http://www.ukrstat.gov.ua/druk/publicat/kat_u/ 2020/zb/09/zb_sg_Ukr_2019.pdf (дата звернення 21.04.2021).

17. Розміри прожиткового мінімуму в Україні. Дебет-кредит: сервіси для бухгалтера. URL: https://services.dtkt.ua/catalogues/indexes/1 (дата звернення 17.03.2021).

18. SIA «Latvijas Lauku konsultāciju un izglītības centrs» Gada pārskats par 2019 gadu. №40003347699. URL: http://new.llkc.lv/sites/default/files/baskik_p/ pielikumi/llkc_gada_parskats_2019_0.pdf (дата звернення 07.05.2021р.)

19. Офіційний курс Євро на 23 грудня 2019 р. Міністерство фінансів України. URL: https://minfin.com.ua/ua/currency/nbu/eur/2019-12-23/ (дата звернення 08.05.2021).

20. Eesti põllu-ja maamajanduse nõuandesüsteemi arengukava aastateks 2012 2020. URL: https://www.pikk.ee/upload/files/N\%C3\%B5uandeteenistus/ Arengukava\%202012-2020.pdf (дата звернення 07.05.2021).

21. Sprawozdania roczne $\mathrm{z}$ realizacji PROW 2014-2020 URL: https://www.gov.pl/web/rolnictwo/sprawozdania-roczne-z-realizacji-prow-2014-2020 (дата звернення 21.04.2021).

\section{References}

1. McNamara, P. (2014). A review of sustainable financing of extension services in developing countries. MEAS discussion paper. University of Illinois at Urbana-Champaign. Retrieved from: https://meas.illinois.edu/wpcontent/uploads/2015/04/McNamara-2014-Finance-MEAS-Discussion-Paper.pdf [in English].

2. Feder, G., Willett, A., \& Zijp, W. (1999). Agricultural Extension: Generic Challenges and Some Ingredients for Solutions. ssrn.com. Retrieved from: https://ssrn.com/abstract=620481 [in English].

3. Shchodo derzhavnoi pidtrymki rozvytku silskogospodarskogo doradnytstva v Ukrajini. Analiticha zapyska [Regarding state support for the development of 


\section{EФM}

http://efm.vsau.org/

agricultural advisory services in Ukraine. Analytical note]. Natsionalnyi instytut stratehichnykh doslidzhen - National Institute for Strategic Studies. Retrieved from: http://www.niss.gov.ua/articles/1521/ [in Ukranian].

4. Kropyvko, M.F. (2011). Shlyahy rozvytku silskogospodarskogo doradnytstva $\mathrm{v}$ Ukraini [Ways of development of agricultural extension in Ukraine]. Naukovyi visnyk NUBiP Ukrainy. Seriia "Ekonomika, ahrarnyi menedzhment, biznes» - Scientific Bulletin of NULES of Ukraine. Series «Economics, agricultural management, business», 168, 10-16 [in Ukranian].

5. Broyaka, A.A. (2016). Kontseptualni zasady organizatsii efektyvnogo informatsiino konsultatsiinogo zabezpechennia silskogo gocpodarstva [Conceptual framework of organization an effective information and advisory support of agriculture]. Agrosvit - Agroworld, 21, 36-42 [in Ukranian].

6. Pokhylenko, N.M., \& Korinets, R.Ya. (2018). Finansuvannia systemy silskohospodarskoho doradnytstva [Financing of the agricultural extension system]. Hlobalni ta natsionalni problemy ekonomiky - Global and national economic problems, 23, 109-115 [in Ukranian].

7. Pro rezultati auditu efectivnosti vykoristannia koshtiv derzhavnoi tsilovoi program rozvitku ukrainskogo sela do 2015 roky [About results of audit of efficiency of use of means of the state budget directed on performance of the state target program of development of the Ukrainian village for the period till 2015]. Kyiv: Rahuncova palata Ukrajiny [in Ukranian].

8. Pasport budgetnoi programy 2801230 «Finansova pidtrimka rozvytku fermerskih gospodarstv» [Passport of the budget program 2801230 for 2019 «Financial support for farm development»]: Ministry of Agrarian Policy and Food of Ukraine, Order № 329, 18.06.2019. Retrieved from: https://agro.me.gov.ua/ua/napryamki/finansova-politika/byudzhetnij-proces/pasportibyudzhetnih-program/pasporti-byudzhetnih-program-na-2019-rik [in Ukranian].

9. Derzhpidtrymka APK: focus u 2020 rotsi ta strategiia na 2021-2023 roky. Agropolit [State support of agro-industrial complex: focus in 2020 and strategy for 2021-2023. Agropolit]. agropolit.com. Retrieved from: https://agropolit.com/spetsproe kty/783-derjpidtrimka-apk-fokus-u-2020-rotsi-tastrategiya-na-20212023-roki [in Ukranian].

10. Reiestr silskogospodarskih doradchyh sluzhb. Informatsiino-analitychnyi portal APK Ukrainy [Register of agricultural extension services. Information and analytical portal of the AIC of Ukraine]. agro.me.gov.ua. Retrieved from: https://agro.me.gov.ua/ua/file-storage/reyestr-doradchih-sluzhb-ta-doradnikiv [in Ukranian].

11. Misra, D.C. (1997). Monitoring extension programmes and resources. Improving agricultural extension. A reference manual. Food and Agriculture Organization of the United Nations. fao.org. Retrieved from: http://www.fao.org/ docrep/W5830E/w5830e0j.htm\#monitoringindicators [in English].

12. Zvit vykonannia pasporta byudzhetnoi programy KPKVK 6591060. 


\section{EФM}

http://efm.vsau.org/

[Report on the implementation of the passport of the budget program KPKVK 6591060]. Natsionalna Academiya Agrarnih Nauk Ukrainy. naas.gov.ua. Retrieved from: http://naas.gov.ua/upload/iblock/df5/\%D0\%B7\%D0\%B2\%D1\%96\%D1\%82 \%2065 91060.pdf [in Ukranian].

13. Stan finansuvannya APK u 2018 rotsi [The state of financing of the agroindustrial complex in 2018]. Informatsiino-analitychnyi portal APK Ukrainy. agro.me.gov.ua. Retrieved from: https://agro.me.gov.ua/ua/napryamki/finansovapolitika/finansuvannya-z-derzhavnogo-byudzhetu/stan-finansuvannya-apk-u-2018roci [in Ukranian].

14. Stan finansuvannya APK u 2019 rotsi [The state of financing of the agroindustrial complex in 2019]. Informatsiino-analitychnyi portal APK Ukrainy. agro.me.gov.ua. Retrieved from: https://agro.me.gov.ua/ua/napryamki/finansovapolitika /finansuvannya-z-derzhavnogo-byudzhetu/stan-finansuvannya-apk-u-2019roci [in Ukranian].

15. Natsionalni rahunky (VVP) [National Accounts (GDP)]. Derzhavna sluzhba statystyky Ukrainy. ukrstat.gov.ua. Retrieved from: http://ukrstat.gov.ua/imf/arhiv/nr/nr2016_2020_u.htm [in Ukranian].

16. Silske gospodartvo Ukrainy za 2019 rik. Statistichnii zbirnik [Agriculture of Ukraine for 2019. Statistical collection]. ukrstat.gov.ua. Retrieved from: http://www.ukrstat.gov.ua/druk/publicat/kat_u/2020/zb/09/zb_sg_Ukr_2019.pdf [in Ukranian].

17. Rozmiry prozhytkovogo minimumu v Ukraini. Debet-kredit: servisy dlia buhgaltera [The size of the subsistence level in Ukraine. Debit credit: services for an accountant]. services.dtkt.ua. Retrieved from: https://services.dtkt.ua/catalogues/indexes/1 [in Ukranian].

18. SIA «Latvijas Lauku konsultāciju un izglìtīibas centrs» Gada pārskats par 2019 gadu. №40003347699. new.llkc.lv. Retrieved from: http://new.llkc.lv/sites/default/files/baskik_p/pielikumi/llkc_gada_parskats_2019_0.p df [in Latvian].

19. Ofitsiinyi kurs yevro na 23 grudnya 2019 [The official exchange rate of the Euro on December 23, 2019]. Ministerstvo finansiv Ukrainy. minfin.com.ua. Retrieved from: https://minfin.com.ua/ua/currency/nbu/eur/2019-12-23/ [in Ukranian].

20. Eesti põllu-ja maamajanduse nõuandesüsteemi arengukava aastateks 2012 2020. pikk.ee. Retrieved from: https://www.pikk.ee/upload/files/ N\%C3\%B5uandeteenistus/Arengukava\%202012-2020.pdf [in Estonian].

21. Sprawozdania roczne z realizacji PROW 2014-2020. gov.pl. Retrieved from: https://www.gov.pl/web/rolnictwo/sprawozdania-roczne-z-realizacji-prow2014-2020 [in Polish].

\section{Відомості про авторів}

ПОХИЛЕНКО Наталія Михайлівна - кандидат економічних наук, 
старший науковий співробітник відділу організації менеджменту, публічного управління та адміністрування, ННЦ «Інститут аграрної економіки» (03127, м. Київ, вул. Героїв Оборони, 10, e-mail: pohylenko29@gmail.com).

КОРІНЕЦЬ Роман Ярославович - кандидат економічних наук, радник Національної асоціації сільськогосподарських дорадчих служб України (03127, м. Київ, вул. Героїв Оборони, 10, e-mail: rkorinets@gmail.com).

POKHYLENKO Nataliia - Candidate of Economics Science, Senior Research Fellow of the Department of Organization Management, Public Administration and Administration, National Scientific Center «Institute of Agrarian Economics» (03127, Kyiv, 10, Geroiv Oborony Str., e-mail: pohylenko29@gmail.com).

KORINETS Roman - Candidate of Economics Science, Honorary President of the National Association of Agricultural Advisory Services of Ukraine (03127, Kyiv, 10, Geroiv Oborony Str., e-mail: rkorinets@gmail.com).

ПОХИЛЕНКО Наталия Михайловна - кандидат экономических наук, старший научный сотрудник отдела организации менеджмента, публичного управления и администрирования, Национальный научный центр «Институт аграрной экономики» $(03127$, г. Киев, ул. Героев Обороны, 10, e-mail: pohylenko29@gmail.com).

КОРИНЕЦ Роман Ярославович - кандидат экономических наук, почетный президент Национальной ассоциации сельскохозяйственных консультационных служб Украины (03127, г. Киев, ул. Героев Обороны, 10, e-mail: rkorinets@gmail.com).

УДК: 338.439.6-044.247

DOI: $10.37128 / 2411-4413-2021-3-6$

УДОСКОНАЛЕННЯ

СИСТЕМИ

УПРАВЛЯННЯ

ЯКІСТЮ ТА

БЕЗПЕЧНІСТЮ

АГРОХАРЧОВОЇ

ПРОДУКЦІї В

УМОВАХ

СВРОІНТЕГРАЦІЙНИХ ПРОЦЕСІВ
БРОЯКА А.А.,

кандидат економічних наук, доцент, декан факультету економіки та

підприємництва,

Вінницький національний аграрний університет

(м. Вінниця)

У статті досліджено сутність та значення системи управління якістю у процесі забезпечення якості та безпечності агрохарчової продукиії, розглянуто основні аспекти та передумови ї̈ запровадження вітчизняними підприємствами в контексті реалізачї Угоди про асоціачію Украйни з Свропейським Союзом. Проаналізовано нормативно-правові документи, які регламентують питання безпечності агрохарчових продуктів, рівень їхньої 